Fixed Point Theory, 20(2019), No. 2, 417-430

DOI: $10.24193 /$ fpt-ro.2019.2.27

http://www.math.ubbcluj.ro/ nodeacj/sfptcj.html

\title{
ON THE HYPERSTABILITY OF JENSEN FUNCTIONAL EQUATION IN 2-BANACH SPACES
}

\author{
MUAADH ALMAHALEBI*, SAMIR KABBAJ** AND GWANG HUI KIM***,1 \\ *Department of Mathematics, Faculty of Sciences \\ Ibn Tofail University, BP:14000, Kenitra, Morocco \\ E-mail: muaadh1979@hotmail.fr \\ ** Department of Mathematics, Faculty of Sciences \\ Ibn Tofail University, BP:14000, Kenitra, Morocco \\ E-mail: samkabbaj@yahoo.fr \\ *** Department of Mathematics, Kangnam University \\ Yongin, Gyeonggi, 16979, Republic of Korea \\ E-mail: ghkim@kangnam.ac.kr
}

\begin{abstract}
In this paper, we make 2-Banach version of hyperstability results for the Jensen equation. Indeed, by using Brzdęk's fixed point theorem [15], we present some hyperstability results for the Jensen equation in 2-Banach spaces.

Key Words and Phrases: Stability, hyperstability, 2-Banach space, Jensen functional equation. 2010 Mathematics Subject Classification: 39B82, 39B52, 47H10.
\end{abstract}

\section{REFERENCES}

[1] L. Aiemsomboon, W. Sintunavarat, On new stability results for generalized Cauchy functional equations on groups by using Brzdȩk's fixed point theorem, J. Fixed Point Theory Appl., 18(2016), 45-59.

[2] L. Aiemsomboon, W. Sintunavarat, On generalized hyperstability of a general linear equation, Acta Math. Hungar., 149(2016), 413-422.

[3] M. Almahalebi, A. Chahbi, Hyperstability of the Jensen functional equation in ultrametric spaces, Aequat. Math., 91(2017), no. 4, 647-661.

[4] M. Almahalebi, A. Charifi, S. Kabbaj, Hyperstability of a monomial functional equation, J. Scientific Research Reports, 3(2014), no. 20, 2685-2693.

[5] M. Almahalebi, A. Charifi, S. Kabbaj, Hyperstability of a Cauchy functional equation, J. Comput. Anal. Appl., 6(2015), no. 2, 127-137.

[6] M. Almahalebi, S. Kabbaj, Hyperstability of a Cauchy-Jensen type functional equation, Advances in Research, 2(2014), no. 12, 1017-1025.

[7] M. Almahalebi, C. Park, On the hyperstability of a functional equation in commutative groups, J. Comput. Anal. Appl., 20(2016), no. 1, 826-833.

[8] T. Aoki, On the stability of the linear transformation in Banach spaces, J. Math. Soc. Japan, $\mathbf{2}(1950), 64-66$.

\footnotetext{
${ }^{1}$ Corresponding author.
} 
[9] D.G. Bourgin, Classes of transformations and bordering transformations, Bull. Amer. Math. Soc., 57(1951), 223-237.

[10] J. Brzdęk, A note on stability of additive mappings, in: Stability of Mappings of Hyers-Ulam Type, Rassias, T.M., Tabor, J. (eds.), Hadronic Press, Palm Harbor, 1994, $19-22$.

[11] J. Brzdęk, Stability of additivity and fixed point methods, Fixed Point Theory Appl., 2013, 2013:265, pp.9.

[12] J. Brzdęk, Hyperstability of the Cauchy equation on restricted domains, Acta Math. Hungar., 141(2013), 58-67.

[13] J. Brzdęk, L. Cadăriu, K. Ciepliński, Fixed point theory and the Ulam stability, J. Funct. Spaces, 2014(2014), Article ID 829419, pp. 16.

[14] J. Brzdęk, K. Ciepliński, A fixed point approach to the stability of functional equations in nonArchimedean metric spaces, Nonlinear Anal., 74(2011), 6861-6867.

[15] J. Brzdęk, K. Ciepliński, On a fixed point theorm in 2-Banach spaces and some of its applications, Acta Math. Scientia, 38(2018), 377-390.

[16] J. Brzdȩk, W. Fechner, M.S. Moslehian, J. Sikorska, Recent developments of the conditional stability of the homomorphism equation, Banach J. Math. Anal., 9(2015), 278-327.

[17] J. Brzdȩk, D. Popa, I. Raşa, B. Xu, Ulam Stability of Operators, Mathematical Analysis and its Applications, vol. 1, Academic Press, Elsevier, Oxford 2018.

[18] S. Gähler, 2-metrische Räume und ihre topologische Struktur, Math. Nachr., 26(1963), 115-148.

[19] S. Gähler, Linear 2-normiete Räumen, Math. Nachr., 28(1964), 1-43.

[20] D.H. Hyers, On the stability of the linear functional equation, Proc. Natl. Acad. Sci. U.S.A., 27(1941), 222-224.

[21] W.-G. Park, Approximate additive mappings in 2-Banach spaces and related topics, J. Math. Anal. Appl., 376(2011), 193-202.

[22] W. Park, J. Bae, B. Chung, On an additive-quadratic functional equation and its stability, J. Appl. Math. Computing, 18(2005), 563-572.

[23] Th. M. Rassias, On the stability of the linear mapping in Banach spaces, Proc. Amer. Math. Soc., 72(1978), 297-300.

[24] Th. M. Rassias, Problem 16; 2. Report of the 27th International Symposium on Functional Equations, Aequationes Math., 39(1990), 292-293.

[25] Th. M. Rassias, On a modified Hyers-Ulam sequence, J. Math. Anal. Appl., 158(1991), 106-113.

[26] S.M. Ulam, Problems in Modern Mathematics, Science Editions, John-Wiley \& Sons Inc., New York, 1964.

Received: April 16, 2018; Accepted: October 18, 2018. 
